\title{
Contamination of small urban watercourses on the example of a stream in Krakow (Poland)
}

\author{
Urszula Aleksander-Kwaterczak $^{1}$ (D) . Dominika Plenzler ${ }^{1}$
}

Received: 29 July 2018 / Accepted: 27 July 2019 / Published online: 16 August 2019

(C) The Author(s) 2019

\begin{abstract}
The urbanization of catchments is consistently accompanied by a decrease of the stream condition. The case study concerns one of the urban streams in Krakow (Poland). The aim was to show the pollutant load which can enter the Vistula River from even a very small inflow. Samples of water, suspended particulate matter and bottom sediment were collected. Values of $\mathrm{pH}$, Eh and electrolytic conductivity were measured in situ and the contents of macroelements-cations and inorganic anions - as well as trace elements were analysed by means of different instrumental methods. The results obtained are related to normative values, geochemical background and different classifications. The exceedance of permissible values for water by electrical conductivity, calcium, chlorides and cadmium concentrations in all of the sampling locations was stated. The high content of heavy metals in the bottom sediment was found especially for zinc (to $929 \mathrm{mg} / \mathrm{kg}$ ), lead (to $131 \mathrm{mg} / \mathrm{kg}$ ) and cadmium (to $10 \mathrm{mg} / \mathrm{kg}$ ). It is shown that pollutants carried along with the waters and sediments of the stream constitute a continuous source of pollution of the Vistula River. It seems important to measure the concentration of some elements not only in the sediment of the biggest rivers but also in the smaller streams, ditches and rain collectors. Only management in the entire catchment system and inventory of pollution sources can give some positive results in improving the quality of urban watercourses.
\end{abstract}

Keywords Urban watercourse $\cdot$ Heavy metal $\cdot$ Pollution assessment $\cdot$ Ecological potential degradation

\section{Introduction}

The trend of urbanization entails large challenges in terms of water supply and sanitation management. Next to natural river courses, which are recognized as rivers, streams, brooks or other waters, flowing continually or periodically, in their natural river-beds (according to the Act on Water Law, Dz.U.2017.1566), urbanized watercourses occur. They are understood as streams and brooks of a drainage character within city areas. Their maximum ratio of breadth to depth equals $20: 1$ and the average daily rate of flow is not higher than $1.5 \mathrm{~m}^{3} / \mathrm{s}$ (Osmulska-Mróz 1990). Their small, transformed basins have low hydrological inertia; therefore, the impact of external factors is revealed in them almost

Urszula Aleksander-Kwaterczak

aleksa@geol.agh.edu.pl

1 Faculty of Geology, Geophysics and Environmental Protection, AGH University of Science and Technology, Al. A. Mickiewicza 30, Krakow, Poland immediately and causes the high variability of water quality indicators (Rajda and Kanownik 2005).

The urban development reduces the ability of streams to function as natural ecosystems (Bernhardt and Palmer 2007). The urbanization of catchments is consistently accompanied by a decrease of the stream condition which is associated with the hydrological, chemical and biological stressors described as "urban stream syndrome" (Brabec et al. 2002; Walsh et al. 2005). The development of urban infrastructure often leads to an elimination of rivers and their valleys. The watercourses very often lose their natural environmental values with developed small retention, either disappearing or otherwise becoming open or partly covered sewers. In the city centre, they are locked in underground channels and transport contaminants to greater rivers (Wardas et al. 2006; Kobojek 2015). The increasing degree of urbanization has resulted in larger amounts of impervious surfaces such as roads, parking lots, and rooftops and, therefore, a decrease in the number of natural lands as well as significant changes to both the quality and quantity of the storm water runoff (Bannerman et al. 1993). It is important because the 
watershed land cover and land use may mitigate or exacerbate the effects of metal pollution on streams (Tomczyk et al. 2018). It is known that increasing urbanization has been linked to increases in stream metal concentrations (e.g. Paul and Meyer 2001; Das et al. 2009).

Within small urbanized watercourse catchments, the accumulation of heavy metals in bottom sediments takes place and, when combined with salinity and eutrophication, causes the degradation of ecological potential and the extinction of sensitive species of water organisms (Wardas et al. 2006). Field macroinvertebrate surveys have established a pattern of stream ecological decline along a gradient of urbanization, consistent with the impact of contaminated sediment (Marshall et al. 2010).

Sediments can be adopted as an efficient indicator for monitoring heavy metal pollution levels and pollution sources in aquatic environments (George et al. 2016). Heavy metals do not form a stable system in the environment, they may be released into water columns by physical, chemical and biological processes, which may affect their properties and forms of occurrence and in turn can increase pollution levels of surrounding waters. Therefore, their size in the ecosystem may change over time (Aleksander-Kwaterczak and Helios-Rybicka 2009; Shafie et al. 2014).

The whole area of Krakow is located within the Vistula River catchment and its tributaries. It is estimated that within the borders of Krakow, there is $194 \mathrm{~km}$ of permanent watercourses and larger drainage ditches, with unregulated watercourses (128 km) dominating (Dynowski 1974).

The small watercourse analysed is only one of them. This research aims to show how large pollutant loads can be introduced into rivers only by small watercourses in urbanized areas. Such watercourses are very poorly monitored. Meanwhile, continuous pollutant loads introduced with them into larger watercourses, often used as a source of drinking water, cause their continued pollution. It also aims to show the importance of managing the water environment quality at the catchment scale. Merely such a system can be effective in striving to improve the quality of the Vistula River. And only such a system will allow to reduce pollutions carried to the Baltic Sea.

\section{Description of the study area}

The small watercourse, whose name is difficult to find on maps, is located in Nowa Huta district of the Krakow city (southeastern part of Poland, Fig. 1). Nowa Huta is the easternmost district of Krakow with more than 200,000 inhabitants. It was created in 1949 as a separate city and was planned as a huge centre of heavy industry, populated primarily by industrial workers (Karnasiewicz 2003). The Krakow Industrial District, comprising seven neighbouring towns, specializes in the metallurgical, electromechanical and chemical industries. One of the largest industrial plants is ArcelorMittal, which manufactures steel is located in Nowa Huta. Therefore, this area is considered the most polluted in Krakow.

Analysed watercourse is a left tributary of the Vistula River, the longest and largest river in Poland (Fig. 1). It is named as "small" because the length of the stream is about $5 \mathrm{~km}$, its catchment area is nearly $9.5 \mathrm{~km}^{2}$ and average flow is $<1 \mathrm{~m}^{3} / \mathrm{s}$. Short drainage ditches go into the analysed stream in the area of Nowa Huta Meadows-a huge green area, a remnant of the former riverbed of the Vistula with
A

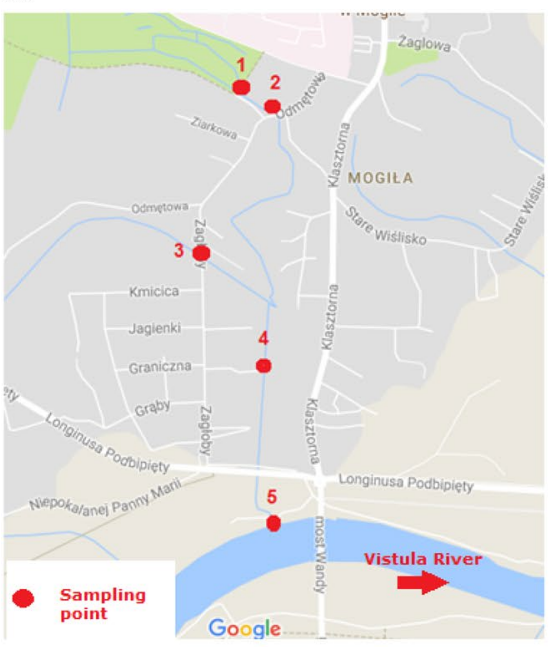

B

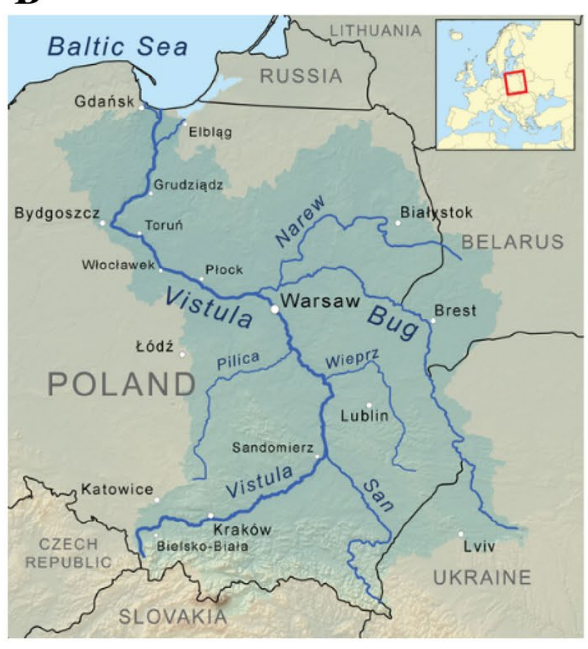

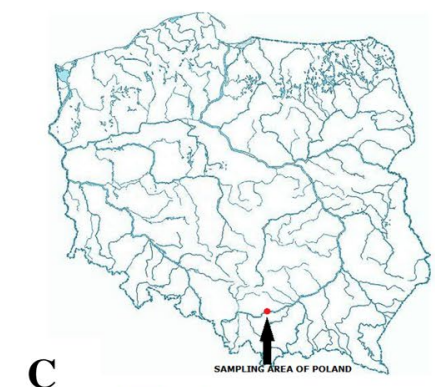

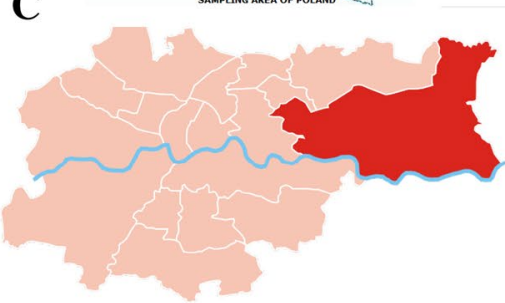

Fig. 1 Localization of the study area and sampling sites: a sampling point localization (on a map from https://maps.google.com), b Vistula river basin and c location of Nowa Huta within Krakow (https://en.wikipedia.org/, CC BY-SA 3.0) 
370 plant and 69 bird species, many of which have been entered in the Red Book of Endangered Species (published by the International Union for Conservation of Nature, IUCN). Next, the stream flows through built-up areas which are the dominant form of this region land development (about 80\%) (BIP 2015). According to physical and geographical regionalization, the described area is classified as the Podkarpacka Provinces, the Sandomierska Basin Macroregion and Nadwiślańska Plain Microregion (Kondracki 2002). In terms of geomorphology, it is located within the Pradolina of Vistula (Tyczyńska 1968), which includes plains accumulation terrace. Other, larger varieties of terrain are of an anthropogenic origin.

\section{Materials and methods}

\section{Field and laboratory analyses}

Five sampling points were selected along the whole length of the stream. Due to the large buildings of the area and limited access to particular sections of the stream, sampling points were not evenly distributed (Fig. 1). The distance between sampling points ranged from about $100 \mathrm{~m}$ (from point 1 to point 2) to about $400 \mathrm{~m}$ (from 4 to 5 point). The first point was located near the Nowa Huta Meadows and the last one at the mouth of the stream to the Vistula River. At each point, water and bottom sediment samples were collected in the autumn season. Water samples were collected again at the beginning of the summer at the two selected sampling points to check seasonal changes.

\section{Water analysis}

Water samples were taken from the shore directly into clean polypropylene bottles. The $\mathrm{pH}$ ( $\mathrm{pH}$ meter, Elmetron CP-105; GP-105; accuracy \pm 0.02), redox potential (Eh, Elmetron CP-105; GR-105 k; accuracy $\pm 1.0 \mathrm{mV}$ ), temperature (Elmetron $\mathrm{CP}-105$; accuracy $\pm 0.08{ }^{\circ} \mathrm{C}$ ), electrical conductivity (EC, Elmetron CC-105; accuracy $\pm 1 \%$ ) and oxygen content (Elmetron $\mathrm{CO}-105$; GO-105; accuracy $\pm 0.2 \%$ ) were measured in situ. Each sample was filtered also in the field using single-use cellulose acetate syringe filters of $0.45 \mu \mathrm{m}$ and was kept in a refrigerator at $4{ }^{\circ} \mathrm{C}$ until analysed (according to the European Standard EN ISO 5667-3 2018). Major anions $\left(\mathrm{Cl}^{-}, \mathrm{NO}_{3}{ }^{-}, \mathrm{NO}_{2}{ }^{-}, \mathrm{SO}_{4}{ }^{2-}, \mathrm{PO}_{4}{ }^{3-}, \mathrm{HCO}_{3}{ }^{-}\right.$and $\left.\mathrm{F}^{-}\right)$and macroions $\left(\mathrm{Ca}^{2+}, \mathrm{Mg}^{2+}, \mathrm{Na}^{+}, \mathrm{K}^{+}\right.$and $\left.\mathrm{HN}^{4+}\right)$ were determined using ion chromatography (DIONEX, IC25 Ion Chromatograph, (according to PN-EN ISO 10304-1 2009; PN-EN ISO 14911 2002) at the Polish Academy of Sciences in Krakow. Standard reference materials (Canadian waters Hamilton-20) were employed to determine the accuracy of ion analyses.
Samples intended for measuring the dissolved phase of metal concentrations by spectrometry techniques were acidified with ultrapure nitric acid $65 \%$ to a $\mathrm{pH}$ below 2. Major cations and elements were analysed using an inductively coupled plasma mass spectrometer (ICP-MS, ELAN 6100, PerkinElmer) or an inductively coupled plasma optical emission spectrometer (ICP-OES, Plasm 40, Perkin Elmer) in a certified Hydrogeochemical Laboratory (PCA certificate, no AB 1050) in the AGH University of Science and Technology in Krakow, according to standard certified analytical quality control procedures (PN-EN ISO 17294-1 2007; PN-EN ISO 11885 2009).

\section{Suspended particulate matter analysis}

The suspended matter was separated from the value of $2 \mathrm{~L}$ of water using a filter with the ground clearance of $0.45 \mu \mathrm{m}$ and an apparatus for sterile pressure filtration (type 16510, PC). Heavy metal concentration was determined using the ICP-MS method (ELAN 6100, PerkinElmer) after extraction with $10 \mathrm{~cm}^{3}$ of $65 \%$ nitric acid (p.a.) in High-Temperature Digestion Systems (SCP Science-Digi PREP HT; $120^{\circ} \mathrm{C}$, $2 \mathrm{~h}$ ). The RSD values ranged for $\mathrm{Cd}$ from 2.75 to $6.06 \%$, for $\mathrm{Cu}$ from 1.11 to $4.24 \%$, Ni from 1.33 to $3.91 \%$, $\mathrm{Pb}$ from 4.51 to $12.14 \%$ and for $\mathrm{Zn}$ from 0.18 to $3.12 \%$.

\section{Sediment analysis}

Sediment samples were collected directly from the shore with a special plastic scoop from the surface layer $(5-10 \mathrm{~cm})$ into polyethylene bags and were placed in an ice cooler and transported to the laboratory as soon as possible. The $\mathrm{pH}$ (pH meter, Elmetron CP-105; GP-105; accuracy \pm 0.02), redox potential (Eh, Elmetron CP-105; GR-105k; accuracy $\pm 1.0 \mathrm{mV}$ ), temperature (Elmetron CP-105; accuracy $\pm 0.08{ }^{\circ} \mathrm{C}$ ), electrical conductivity (EC, Elmetron $\mathrm{CC}-105$; accuracy $\pm 1 \%$ ) were measured in situ.

Water content (loss of mass at $105^{\circ} \mathrm{C}$ ), LOI (loss of mass at $550{ }^{\circ} \mathrm{C}$, laboratory muffle furnace) and carbonate content (Scheibler's method according to PN-EN ISO 10693 2014-06) were analysed on bulk sediment samples. Grain size fraction was established according to PN-B-02480 1998. Heavy metal concentrations were determined using the F-AAS method (iCE3000, Thermo Scientific) after extraction with $10 \mathrm{~cm}^{3}$ of $65 \%$ nitric acid (p.a.) in HighTemperature Digestion Systems (SCP Science-Digi PREP $\mathrm{HT} ; 120{ }^{\circ} \mathrm{C}, 2 \mathrm{~h}$ ). The RSD values for all analysed metals were below $5 \%$ (if the value was higher, the analysis was repeated).

The analyses were performed according to a standard certified analytical quality control procedure. Blanks and standard reference materials (Sediment river 1646) were analysed at regular intervals (one blank and one standard for each set 
of ten samples) to assess the precision and accuracy of the measurements. For comparison, the dilution analysed by the F-AAS was also measured by the ICP-MS method. Results for all analysed metals were only slightly $(<5 \%)$ different, which confirms very good analytical quality.

\section{Methodology of indexes}

Different quality indices were used in this study to determine the degree of contamination of the analysed sediments.

\section{The geoaccumulation index (Igeo)}

Igeo was originally used for the pollution assessment of heavy metals in sediment by Müller (1969). It allows to compare current concentrations with pre-industrial levels according to the following equation:

Igeo $=\log _{2} \frac{C n}{1.5 \times B n}$,

where $C n$ is the measured content of the metal $n$ and $B n$ is the geochemical background for metal.

The constant term 1.5 is used for possible lithological variations in the background value.

The Igeo values of each heavy metal were classified into seven grades: from class 0 (unpolluted; Igeo $\leq 0$ ) to class VI (extremely polluted; Igeo $>5$ ).

\section{The pollution load index (PLI)}

The PLI index was suggested by Tomlinson et al. (1980) for detecting pollution with heavy metals in each respective sample locations. It was calculated using the following equation:

$\mathrm{PLI}=(\mathrm{CF} 1 \times \mathrm{CF} 2 \times \mathrm{CF} 3 \times \ldots \mathrm{CF} n)^{1 / n}$,

where $\mathrm{CF}$ is the concentration factors for individual metal:

$\mathrm{CF}=\frac{C}{B_{n}}$,

$C$ is the metal concentration in the analysed sample site and $B_{n}$ is the pre-industrial reference level for the substance.

The value of PLI $<1$ indicates no pollution with heavy metal contamination, when $1 \leq \mathrm{PLI}<2$ moderate pollution, $2 \leq \mathrm{PLI}<3$ heavy pollution and PLI $\geq 3$ extremely heavy pollution (Tomlinson et al. 1980; Ghaleno et al. 2015).

\section{The contamination factor $\left(C_{\mathrm{f}}\right)$}

The factor $C_{\mathrm{f}}$ by Hakanson (1980) is used to describe the contamination of an individual toxic substance and calculated as follows:
$C_{\mathrm{f}}^{i}=\frac{C^{i}}{B_{n}^{i}}$

where $C^{i}$ is the mean content of the substance $i$ from at least five sample sites, $B_{n}^{i}$ is the pre-industrial reference level for the substance.

The classification has been accepted as

$C_{\mathrm{f}}<1$-low contamination,

$1 \leq C_{\mathrm{f}}<3$-moderate contamination,

$3 \leq C_{\mathrm{f}}<6$ - considerable contamination,

$C_{\mathrm{f}} \geq 6$-very high contamination.

\section{Degree of contamination $\left(C_{d}\right)$}

$\boldsymbol{C}_{\mathrm{d}}$ index (Hakanson, 1980) is defined as the sum of all contamination factors which provides information about total contamination. It is calculated according to the following equation:

$C_{\mathrm{d}}=\sum_{i}^{n} \mathrm{C}_{\mathrm{f}}^{i}$

where $C_{\mathrm{d}}<8$ is the low degree of contamination, $8 \leq C_{\mathrm{d}}<16$ is moderate degree of contamination, $16 \leq C_{\mathrm{d}}<32$ is considerable degree of contamination, and $C_{\mathrm{d}} \geq 32$ is very high degree of contamination.

\section{The potential ecological risk index (RI)}

The RI index by Hakanson (1980) is defined as

$\mathrm{RI}=\sum_{i}^{m} E_{\mathrm{r}}^{i}$

where

$E_{\mathrm{r}}^{i}=T_{\mathrm{r}}^{i} C_{\mathrm{f}}^{i}$,

$E_{\mathrm{r}}^{i}$ is the potential ecological risk factor for the given substance, and $T_{\mathrm{r}}^{i}$ is the toxic-response factor for a given substance $(\mathrm{Cd}=30, \mathrm{Cu}=5, \mathrm{~Pb}=5, \mathrm{Zn}=1$ and $\mathrm{Ni}=5$ were adopted for calculation).

$\mathrm{RI}<150$-low ecological risk,

$150 \leq \mathrm{RI}<300$-moderate ecological risk,

$300 \leq \mathrm{RI}<600$ — considerable ecological risk for the lake/ basin,

$\mathrm{RI} \geq 600$ —very high ecological risk.

\section{Ecotoxicological classification}

Ecotoxicological classification is used to assess the impact of contaminated bottom sediments on aquatic organisms. PEL and TEL values delineated three ranges of chemical concentrations that were (Smith et al. 1996): 
- rarely-minimal effect range; concentrations equal to and below the TEL,

- occasionally-possible effect range; concentrations above the TEL, but below the PEL,

- frequently-probable effect range; concentrations equal to and above the PEL, associated with adverse biological effects.

\section{Results and discussion}

\section{Water}

The $\mathrm{pH}$ is one of the most important parameters which may change the bioavailability and toxicity of metals to freshwater biota affecting both metal speciation and the binding of metals at the organism-water interface (Meador 1991; Boyd 2015). The $\mathrm{pH}$ of water ranged from 7.43 to 7.69 which indicates the slightly alkaline character of water and may be associated with carbonate rocks occurring in the bedrock. Although $\mathrm{pH}$ with these values should not affect the increase of metal mobility, it should be remembered that there are still acid rains in Krakow. They can cause temporary changes in $\mathrm{pH}$ of the surface water, which has weaker buffer capacities compared to sediment (Ibanez et al. 2010).

The Eh of water varied between +138 and $+180 \mathrm{mV}$ and the oxygen saturation $\left(\mathrm{S}_{\mathrm{O}_{2}}\right)$ was close to $100 \%$. Such values evidenced oxidizing conditions and are characteristic for well-aerated water. This situation favours the processes of self-purification of water.

The geological structure and amount of precipitation affect diversity EC values of surface waters (Boyd 2015). In our study, the results of conductivity measurements ranged between 827 and $1023 \mu \mathrm{S} / \mathrm{cm}$ (Table 1). Such values may result not only from leaching rock components but also from anthropogenic activities.

Taking into account the concentrations of the analysed elements, the highest results were found in many cases for the W2 and W3 water samples (Table 1). Point W3 (Fig. 1) is located at the end of the long ditch. It circumnavigates the Nowa Huta Meadows, then flows through urbanized areas and goes into the analysed stream at its midway point. Water from this watercourse is characterized by relatively high ammonium, potassium, magnesium, calcium, phosphorus, silicon, fluorides, carbonates phosphates, iron, manganese and zinc concentrations. In the upper section of the stream (W1 and W2), concentrations of sodium, chlorides, nitrates, sulphur, cadmium and lead dominated.

To determine the quality of water, limit values were used according to the Ordinance of the Minister of the Environment of 21 July 2016 on the classification of the status of surface waterbodies and environmental quality standards for priority substances (Dz.U. 2016.1187, in accordance with the UE Water Framework Directive 2000/60/EC). The examined stream was defined as an upland carbonate stream with a fine substrate (group 6, Dz.U. 2011.258.1549), strongly or artificially changed.

The biggest problem is the exceedance of permissible values by electrical conductivity, calcium, chlorides and cadmium concentrations which were very high at all the sampling locations and caused the water to be classified as lower than good class ( $<$ II class). The concentration of total suspended matter (SM) was over the normative value only in the case of sample W5. The high variability in phosphorus and phosphate concentrations is reflected in the diversity of water quality classes due to these elements.

The chemical composition of surface water is subject to constant changes. In the riverbed, the dynamics of the variability of the chemical composition of waters is much higher than for the solid phase. Changes in the composition are primarily determined by the geological structure of the catchment, hydro-meteorological conditions, as well as the seasonal dynamics of river runoff (Cameron 1996; Shomar et al. 2005; Sajdak et al. 2018).

Some differences between physico-chemical compositions of water at two sampling points are presented in Table 2. In November, samples were collected during the rainy season, while in June during the rainless period. We can observe that in June water was more oxygenated and slightly more alkaline. Larger differences between the indicators were observed in the upper section of the watercourse than in its lower course. However, to assess seasonal variability in a more reliable way, research should be repeated at all points and much more frequently.

The Pearson's correlation could show linear dependence. If the correlation coefficient between two elements is high (close to 1), this may mean their similar distribution along the river's course. There are some groups of indicators showing large linear interrelationships. The first of them are $\mathrm{NH}_{4}{ }^{+}, \mathrm{K}^{+}, \mathrm{Ca}^{2+}, \mathrm{Mg}^{2+}, \mathrm{HCO}_{3}{ }^{-}, \mathrm{PO}_{4}{ }^{3-}, \mathrm{Mn}^{2+}, \mathrm{Fe}^{2+/ 3+}$ and $\mathrm{SiO}_{2}$. The Pearson's correlation coefficient varies around a value of $r=0.9$ for each couple combination (Table 3a).

The predominant geochemical process in the studied area which is responsible for the presence of the ions $\mathrm{Ca}^{2+}, \mathrm{Mg}^{2+}$, $\mathrm{HCO}_{3}{ }^{-}$is the dissolution of carbonate minerals presented in the bedrock. $\mathrm{Mn}^{2+}$ and $\mathrm{Fe}^{2+/ 3+}$ can have both natural and anthropogenic sources while the presence of $\mathrm{NH}^{4+}, \mathrm{K}^{+}$and $\mathrm{PO}_{4}{ }^{3-}$ may indicate the inflow of municipal sewage (LenartBoron et al. 2016).

The second group consists of $\mathrm{Na}^{+}, \mathrm{Cl}^{-}, \mathrm{NO}_{3}{ }^{-}, \mathrm{SO}_{4}{ }^{2-}$ and $\mathrm{Pb}$ (Table $3 \mathrm{~b}$ ). The relationship between sodium and chlorides is most likely due to the presence of salt $\mathrm{NaCl}$, used for de-icing road surfaces and washed into the basin (Backstrom et al. 2004). The similar distribution of the rests of the parameters can rather only indicate their common source. The large dependence between the heavy metals (Mn with 
Table 1 Characterization of water samples from the analysed stream

\begin{tabular}{|c|c|c|c|c|c|c|c|c|c|}
\hline Element & W1 & W2 & W3 & W4 & W5 & Min. value & Max. value & Average art. & $\begin{array}{l}\text { Threshold } \\
\text { limit values }\end{array}$ \\
\hline $\mathrm{pH}$ & 7.43 & 7.66 & 7.55 & 7.63 & 7.69 & 7.43 & 7.69 & - & $6.6-8.0$ \\
\hline $\mathrm{EC}(\mu \mathrm{S} / \mathrm{cm})$ & 925 & 1023 & 827 & 879 & 1000 & 827 & 1023 & 931 & $\mathbf{5 5 0}$ \\
\hline $\mathrm{S}_{\mathrm{O} 2}(\%)$ & 98 & 99 & 100 & 100 & 97 & 98 & 100 & 99 & No \\
\hline $\mathrm{Eh}(\mathrm{mV})$ & 169 & 162 & 138 & 160 & 180 & 138 & 180 & 162 & No \\
\hline SM density $\left(\mathrm{mg} / \mathrm{dm}^{3}\right)$ & 2.5 & 13.9 & 13.5 & 7.5 & 42.7 & 2.5 & 42.7 & 16.02 & 16.4 \\
\hline \multicolumn{10}{|l|}{$\mathrm{RSD} \%\left(\mathrm{mg} / \mathrm{dm}^{3}\right)$} \\
\hline Ammonium & $\begin{array}{l}0.08 \\
4.71\end{array}$ & $\begin{array}{l}0.11 \\
2.97\end{array}$ & $\begin{array}{l}0.20 \\
2.08\end{array}$ & $\begin{array}{l}0.17 \\
3,27\end{array}$ & $\begin{array}{l}0.17 \\
3,25\end{array}$ & 0.08 & 0.20 & 0.15 & 0.91 \\
\hline Magnesium & $\begin{array}{l}9.28 \\
1.02\end{array}$ & $\begin{array}{l}9.27 \\
0.90\end{array}$ & $\begin{array}{l}13.53 \\
0.31\end{array}$ & $\begin{array}{l}12.24 \\
1.78\end{array}$ & $\begin{array}{l}12.34 \\
1.77\end{array}$ & 9.27 & 13.53 & 11.33 & 16.70 \\
\hline Calcium & $\begin{array}{l}136.31 \\
0.81\end{array}$ & $\begin{array}{l}139.20 \\
0.22\end{array}$ & $\begin{array}{l}159.61 \\
0.47\end{array}$ & $\begin{array}{l}147.80 \\
2.11\end{array}$ & $\begin{array}{l}145.59 \\
1.14\end{array}$ & 136.31 & 159.61 & 145.70 & 65.30 \\
\hline Phosphorus & $\begin{array}{l}0.26 \\
5.52\end{array}$ & $\begin{array}{l}0.40 \\
8.52\end{array}$ & $\begin{array}{l}1.06 \\
8.92\end{array}$ & $\begin{array}{l}0.15 \\
6.36\end{array}$ & $\begin{array}{l}0.66 \\
4.37\end{array}$ & 0.15 & 1.06 & 0.51 & 0.35 \\
\hline Potassium & $\begin{array}{l}0.80 \\
3.03\end{array}$ & $\begin{array}{l}1.17 \\
2.96\end{array}$ & $\begin{array}{l}3.79 \\
1.44\end{array}$ & $\begin{array}{l}3.42 \\
1.33\end{array}$ & $\begin{array}{l}3.16 \\
2.44\end{array}$ & 0.80 & 3.79 & 2.47 & No \\
\hline Sodium & $\begin{array}{l}49.36 \\
0.86\end{array}$ & $\begin{array}{l}50.11 \\
0.12\end{array}$ & $\begin{array}{l}31.66 \\
0.86\end{array}$ & $\begin{array}{l}42.34 \\
2.33\end{array}$ & $\begin{array}{l}42.00 \\
1.42\end{array}$ & 31.66 & 50.11 & 43.09 & No \\
\hline Silicon & $\begin{array}{l}12.62 \\
0.71\end{array}$ & $\begin{array}{l}12.73 \\
0.37\end{array}$ & $\begin{array}{l}23.58 \\
0.96\end{array}$ & $\begin{array}{l}19.72 \\
0.16\end{array}$ & $\begin{array}{l}19.37 \\
0.36\end{array}$ & 12.62 & 23.58 & 8.95 & No \\
\hline Fluorides & $\begin{array}{l}0.03 \\
7.83\end{array}$ & $\begin{array}{l}0.04 \\
7.10\end{array}$ & $\begin{array}{l}0.04 \\
8.13\end{array}$ & $\begin{array}{l}0.04 \\
7.45\end{array}$ & $\begin{array}{l}0.04 \\
7.82\end{array}$ & 0.03 & 0.04 & 0.04 & 1.50 \\
\hline Chlorides & $\begin{array}{l}128.05 \\
0.13\end{array}$ & $\begin{array}{l}128.18 \\
0.12\end{array}$ & $\begin{array}{l}70.14 \\
0.24\end{array}$ & $\begin{array}{l}80.74 \\
0.21\end{array}$ & $\begin{array}{l}82.81 \\
0.20\end{array}$ & 70.14 & 128.18 & 97.98 & 68.00 \\
\hline Nitrates & $\begin{array}{l}3.33 \\
5.71\end{array}$ & $\begin{array}{l}2.85 \\
6.67\end{array}$ & $\begin{array}{l}0.71 \\
16.76\end{array}$ & $\begin{array}{l}2.97 \\
6.39\end{array}$ & $\begin{array}{l}2.65 \\
7.17\end{array}$ & 0.71 & 3.33 & 2.50 & 5.00 \\
\hline Nitrites & $\begin{array}{l}0.02 \\
45.01\end{array}$ & $\begin{array}{l}0.02 \\
35.15\end{array}$ & $\begin{array}{l}0.01 \\
43.11\end{array}$ & $\begin{array}{l}0.23 \\
3.91\end{array}$ & $\begin{array}{l}0.24 \\
3.75\end{array}$ & 0.01 & 0.24 & 0.10 & 0.03 \\
\hline Sulphur & $\begin{array}{l}75.35 \\
0.48\end{array}$ & $\begin{array}{l}74.37 \\
0.48\end{array}$ & $\begin{array}{l}59.26 \\
0.61\end{array}$ & $\begin{array}{l}70.07 \\
0.51\end{array}$ & $\begin{array}{l}71.13 \\
0.50\end{array}$ & 59.26 & 75.35 & 70.04 & 111.40 \\
\hline Phosphates & $\begin{array}{l}0.02 \\
18.00\end{array}$ & $\begin{array}{l}0.06 \\
5.83\end{array}$ & $\begin{array}{l}0.12 \\
2.91\end{array}$ & $\begin{array}{l}0.07 \\
5.00\end{array}$ & $\begin{array}{l}0.06 \\
6.12\end{array}$ & 0.02 & 0.12 & 0.07 & 0.10 \\
\hline Carbonates & $\begin{array}{l}237.83 \\
0.21\end{array}$ & $\begin{array}{l}235.96 \\
0.22\end{array}$ & $\begin{array}{l}342.41 \\
0.15\end{array}$ & $\begin{array}{l}316.31 \\
0.16\end{array}$ & $\begin{array}{l}311.38 \\
0.14\end{array}$ & 235.96 & 342.41 & 288.78 & No \\
\hline \multicolumn{10}{|l|}{$R S D \%\left(\mu \mathrm{g} / \mathrm{dm}^{3}\right)$} \\
\hline Iron & $\begin{array}{l}113.36 \\
3.68\end{array}$ & $\begin{array}{l}132.13 \\
2.35\end{array}$ & $\begin{array}{l}646.43 \\
2.29\end{array}$ & $\begin{array}{l}126.03 \\
1.29\end{array}$ & $\begin{array}{l}248.90 \\
0.85\end{array}$ & 113.36 & 646.43 & 253.37 & No \\
\hline Manganese & $\begin{array}{l}130.55 \\
0.29\end{array}$ & $\begin{array}{l}133.08 \\
0.66\end{array}$ & $\begin{array}{l}668.65 \\
0.57\end{array}$ & $\begin{array}{l}417.41 \\
0.43\end{array}$ & $\begin{array}{l}412.25 \\
0.45\end{array}$ & 133.08 & 668.65 & 352.39 & No \\
\hline Cadmium & $\begin{array}{l}1.47 \\
3.68\end{array}$ & $\begin{array}{l}1.85 \\
5.15\end{array}$ & $\begin{array}{l}1.67 \\
6.17\end{array}$ & $<0.30$ & $\begin{array}{l}0.55 \\
19.51\end{array}$ & $<0.30$ & 1.85 & 1.39 & 0.45 \\
\hline Lead & $\begin{array}{l}2.64 \\
4.77\end{array}$ & $\begin{array}{l}3.19 \\
3.34\end{array}$ & $\begin{array}{l}1.19 \\
2.10\end{array}$ & $\begin{array}{l}1.08 \\
4.19\end{array}$ & $\begin{array}{l}0.81 \\
1.54\end{array}$ & 0.81 & 3.19 & 1.78 & 14.00 \\
\hline Nickel & $\begin{array}{l}2.77 \\
7.32\end{array}$ & $\begin{array}{l}3.02 \\
3.21\end{array}$ & $\begin{array}{l}5.09 \\
2.89\end{array}$ & $\begin{array}{l}3.67 \\
4.70\end{array}$ & $\begin{array}{l}3.27 \\
2.36\end{array}$ & 2.77 & 5.09 & 3.56 & 34.00 \\
\hline Copper & $\begin{array}{l}1.56 \\
4.74\end{array}$ & $\begin{array}{l}2.00 \\
2.61\end{array}$ & $\begin{array}{l}1.91 \\
8.22\end{array}$ & $\begin{array}{l}1.58 \\
1.63\end{array}$ & $\begin{array}{l}1.40 \\
6.64\end{array}$ & 1.40 & 2.00 & 1.69 & 50.00 \\
\hline Zinc & $<1.00$ & $<1.00$ & $\begin{array}{l}6.70 \\
4.48\end{array}$ & $<1.00$ & $\begin{array}{l}2.75 \\
14.67\end{array}$ & $<1.00$ & 6.70 & - & 1000.00 \\
\hline Chromium & $<5.00$ & $\begin{array}{l}5.69 \\
6.27\end{array}$ & $<5.00$ & $<5.00$ & $\begin{array}{l}10.56 \\
7.29\end{array}$ & $<5.00$ & 10.56 & - & $\mathbf{5 0 . 0 0}$ \\
\hline
\end{tabular}

$\mathrm{mg} / \mathrm{dm}^{3}$ is a concentration unit and $\%$ refers to RSD (numbers in italics) $\mu \mathrm{g} / \mathrm{dm}^{3}$ is a concentration unit and \% refers to RSD (numbers in italics)

Bold values indicate statistical description of the data

Italic values indicate standard deviation values

no lack of normative values 
Table 2 Comparison of selected parameters for water in different seasons

\begin{tabular}{|c|c|c|c|c|c|c|c|c|c|}
\hline Sample number & Date & $\mathrm{pH}$ & $\mathrm{Eh}(\mathrm{mV})$ & $\mathrm{PEW}(\mu \mathrm{S} / \mathrm{cm})$ & $\begin{array}{l}\mathrm{Ca} \\
(\mathrm{mg} / \\
\left.\mathrm{dm}^{3}\right)\end{array}$ & $\begin{array}{l}\mathrm{Cl}(\mathrm{mg} / \\
\left.\mathrm{dm}^{3}\right)\end{array}$ & $\begin{array}{l}\mathrm{Cd} \\
(\mu \mathrm{g} / \\
\left.\mathrm{dm}^{3}\right)\end{array}$ & $\begin{array}{l}\mathrm{Pb} \\
(\mu \mathrm{g} / \\
\left.\mathrm{dm}^{3}\right)\end{array}$ & $\begin{array}{l}\mathrm{Ni} \\
(\mu \mathrm{g} / \\
\left.\mathrm{dm}^{3}\right)\end{array}$ \\
\hline \multirow[t]{2}{*}{ W1 } & November & 7.43 & 169 & 925 & 136.31 & 128.05 & 1.47 & 2.64 & 2.77 \\
\hline & June & 7.45 & 212 & 987 & 182.54 & 135.12 & 0.22 & 0.93 & 1.96 \\
\hline \multirow[t]{2}{*}{ W5 } & November & 7.69 & 180 & 1000 & 145.59 & 82.81 & 0.55 & 0.81 & 3.27 \\
\hline & June & 7.84 & 213 & 982 & 185.56 & 91.38 & 0.12 & 0.49 & 2.61 \\
\hline
\end{tabular}

Table 3 Values of the Pearson correlation coefficient between selected parameters

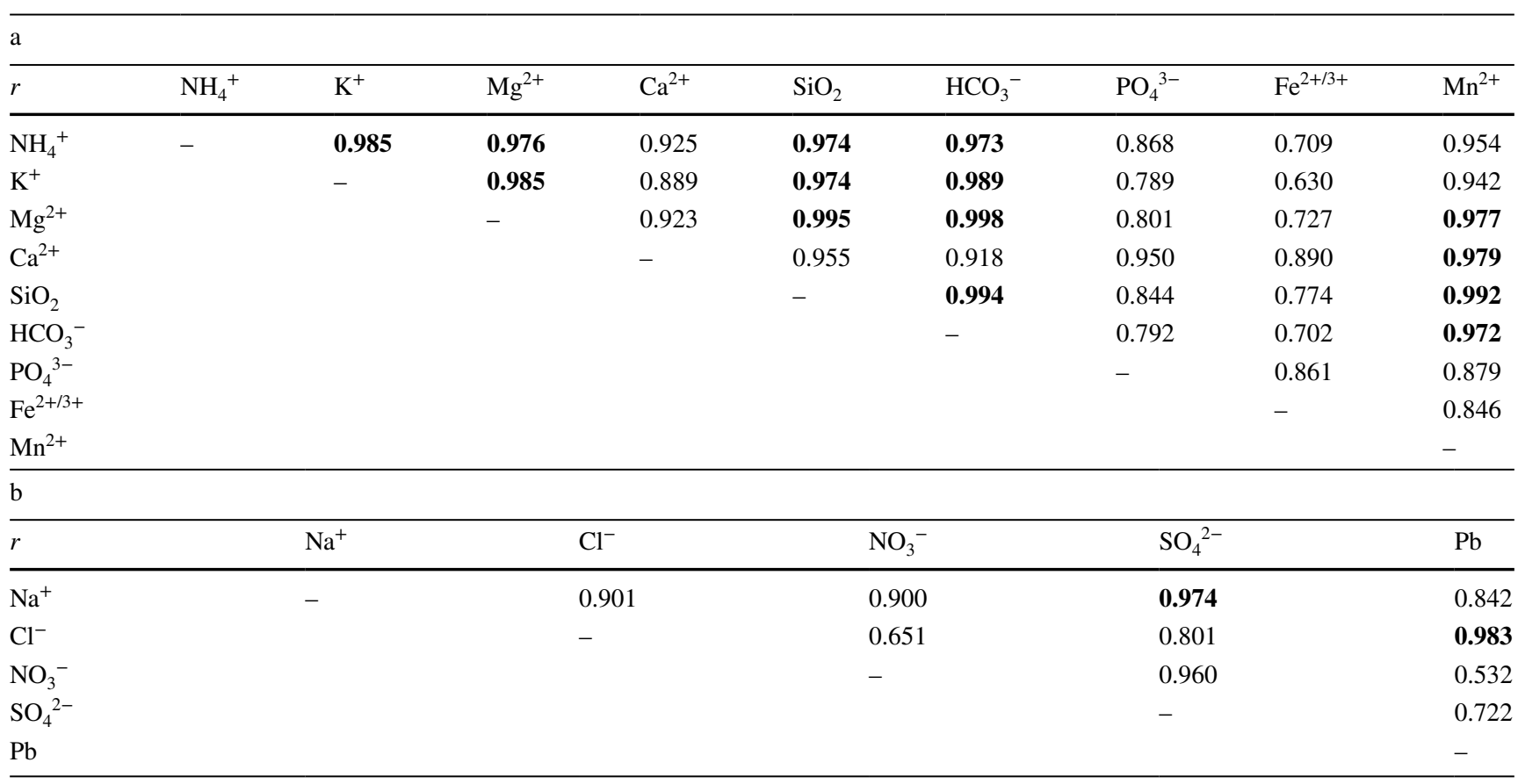

Bold values indicate very strong linear correlation $(r>0.97)$

$\mathrm{Fe}$ and $\mathrm{Zn} ; \mathrm{Cu}$ with $\mathrm{Pb}$ and $\mathrm{Cd}$ ) can indicate their common anthropogenic origin.

The composition of the waters is dependent on many natural or/and anthropogenic factors in the drainage basin and varies with seasonal differences in the volume of runoff, water levels and weather conditions. Changes in chemical composition are generally greatest when available water quantities are low (Bartram and Balance 1996), as in the case of analysed watercourse.

\section{Suspended particulate matter (SPM)}

The suspended particles in a fluvial system can adsorb different contaminants, which are transported downstream and can result in serious impacts on the fluvial system (Grangeon et al. 2012). SPM is mainly composed of inorganic matter with a predominance of clay. However organic matter and hydrous metal oxides can be attached to the surface of particles (Droppo 2001).
In the analysed SPM samples, metal concentrations were calculated as the mass of metal per dry mass of suspended matter which corresponds to the mass of metal per $1000 \mathrm{dm}^{3}$ of stream water. There is a noticeable increase in the metal concentration with the distance from the source of the stream. The highest concentration of metals was observed in the case of point SPM5 (Table 4).

Concentrations obtained for cadmium, copper and lead are within the range estimated as the geochemical background by Adamiec (2003), while the concentration of zinc exceeds this value many times. The LAWA classification (Irmer 1997; LAWA 1998) was used to determine the quality of suspended matter. It was found that because of $\mathrm{Cu}, \mathrm{Ni}, \mathrm{Pb}$ and $\mathrm{Zn}$ concentrations, all of the samples belonged to class I. According to this classification, the suspended particle matter is uncontaminated to moderately contaminated (I class or I-II class) with Cd.

Many research results have revealed that the heavy metal ion concentration in the suspended solids was several times higher than in the bottom sediments (e.g. Adamiec and 
Helios-Rybicka 2002; Helios-Rybicka et al. 2005; Barbusiński et al. 2012). Such a situation can be dangerous because suspended particles are easier to transport; hence, they will easily move down the stream and into the Vistula River carrying loads of heavy metals. They can also easily be carried off the banks of the watercourse, especially during flood periods.

In the case of the watercourse analysed, high concentrations have been found, especially for two metals, this is for zinc and cadmium. However, only in the case of cadmium, these values are comparable to those found in sediments (Tables 4 and 6).

Considering the variability of water suspension density, as expected, it was higher in the rainy period (November). Generally, it is then more contaminated with metals (Table 5).

\section{Bottom sediment}

The chemical composition of stream waters can be affected in various ways by elements occurring in bottom sediments. Some minerals may help stabilize the composition of stream water due to their buffering capacity and others may cause precipitation of dissolved ions (Haris et al. 2017). What's more, sediment acts as a metal reservoir and constitutes a sensible indicator of the background pollution of the watercourse (Shafie et al. 2014).
Bottom sediment samples (S) are generally slightly alkaline. The $\mathrm{pH}$ value oscillated from 6.81 (S1) to 7.89 (S5). Sediments had a low oxidation-reduction potential Eh which ranged between -217 and $-136 \mathrm{mV}$. The unique aspect was the sediment collected at point $\mathrm{S} 3$, where the highest electrolytic conductivity $(1300 \mu \mathrm{S} / \mathrm{cm})$, the content of organic matter (as LOI, $25.94 \%$ ) and calcium carbonate $(57.24 \mathrm{~g} / \mathrm{kg}$, Table 4) were measured.

The spatial variations of metal pollution in sediment depend on the mineral composition as well as particle size distribution (Zhao et al. 1999; Huang and Lin 2003). Generally, heavy metal concentrations increase with decreasing of grain size fraction (Aleksander-Kwaterczak et al. 2004) due to the presence of clay minerals, organic matter, and $\mathrm{Fe} / \mathrm{Mn} /$ $\mathrm{Al}$ oxides in the fine particles (Yao et al. 2015). The results of the granulometric analysis show that a silty-clay grain fraction $(<0.063 \mathrm{~mm})$ dominates in all sediment samples. Their amount ranges from about $45 \mathrm{wt} \%$ to $72 \mathrm{wt} \%$ (Fig. 2, Table 6). The thickest grain fraction $(>2 \mathrm{~mm})$ content does not exceed $10 \mathrm{wt} \%$ and it is the highest in the S2 sample (9.79 wt $\%)$. Such fine-grained sediments can be found in clay minerals characterized by very good sorption properties (Helios-Rybicka et al. 1995; Wilson et al. 2016) which may result in less metal mobility.
Table 4 Heavy metal concentrations in suspended matter

Table 5 Comparison of selected elements for suspended matter in different seasons

\begin{tabular}{lcllllr}
\hline Sample number & $\begin{array}{l}\text { Density } \\
\left(\mathrm{mg} / \mathrm{dm}^{3}\right)\end{array}$ & $\begin{array}{l}\mathrm{Cd}(\mathrm{mg} / \mathrm{kg} \\
\text { d.w. })\end{array}$ & $\begin{array}{l}\mathrm{Cu}(\mathrm{mg} / \\
\mathrm{kg} \mathrm{d.w.})\end{array}$ & $\begin{array}{l}\mathrm{Ni} \\
(\mathrm{mg} / \mathrm{kg} \\
\text { d.w. }\end{array}$ & $\begin{array}{l}\mathrm{Pb}(\mathrm{mg} / \mathrm{kg} \\
\text { d.w. })\end{array}$ & $\begin{array}{l}\mathrm{Zn}(\mathrm{mg} / \mathrm{kg} \\
\text { d.w. })\end{array}$ \\
\hline SPM1 & 2.5 & 0.11 & 1.42 & 3.35 & $<\mathrm{MDL}$ & 9.16 \\
SPM2 & 13.9 & 0.22 & 1.61 & 3.18 & $<\mathrm{MDL}$ & 14.33 \\
SPM3 & 13.5 & 0.14 & 4.73 & 3.37 & $<$ MDL & 7.16 \\
SPM4 & 7.5 & 0.21 & 1.51 & 3.53 & 0.42 & 22.74 \\
SPM5 & 42.7 & 0.38 & 3.65 & 4.86 & 2.55 & 48.93 \\
Minimum & $\mathbf{2 . 5}$ & $\mathbf{0 . 1 1}$ & $\mathbf{0 . 4 2}$ & $\mathbf{3 . 3 5}$ & $\mathbf{0 . 0 0}$ & $\mathbf{9 . 1 6}$ \\
Maximum & $\mathbf{4 2 . 7}$ & $\mathbf{0 . 3 8}$ & $\mathbf{4 . 7 3}$ & $\mathbf{4 . 8 6}$ & $\mathbf{2 . 5 5}$ & $\mathbf{4 8 . 9 3}$ \\
Arithmetic average & $\mathbf{1 6 . 0}$ & $\mathbf{0 . 2 1}$ & $\mathbf{2 . 3 8}$ & $\mathbf{3 . 6 6}$ & - & $\mathbf{1 9 . 8 6}$ \\
Geochemical background according to & $0.15-0.60$ & $10-40$ & n.d. & $12.5-50.0$ & $0.05-0.20$ \\
Adamiec (2003) & & & & & & \\
\hline
\end{tabular}

Bold values indicate standard deviation values

d.w. dry weight, $M D L$ method detection limit, $n . d$. no data

\begin{tabular}{|c|c|c|c|c|c|c|c|}
\hline Sample number & Date & $\begin{array}{l}\text { Density (mg/ } \\
\left.\mathrm{dm}^{3}\right)\end{array}$ & $\begin{array}{l}\text { Cd (mg/ } \\
\text { kg d.w.) }\end{array}$ & $\begin{array}{l}\mathrm{Cu}(\mathrm{mg} / \\
\mathrm{kg} \text { d.w.) }\end{array}$ & $\begin{array}{l}\mathrm{Ni}(\mathrm{mg} / \\
\mathrm{kg} \text { d.w.) }\end{array}$ & $\begin{array}{l}\mathrm{Pb}(\mathrm{mg} / \mathrm{kg} \\
\text { d.w.) }\end{array}$ & $\begin{array}{l}\mathrm{Zn} \\
\text { (mg/ } \\
\mathrm{kg} \\
\text { d.w.) }\end{array}$ \\
\hline \multirow[t]{2}{*}{ SPM1 } & November & 2.5 & 0.11 & 1.42 & 3.35 & $<\mathrm{MDL}$ & 9.16 \\
\hline & June & 1.3 & 0.12 & 5.17 & 2.79 & $<\mathrm{MDL}$ & 4.74 \\
\hline \multirow[t]{2}{*}{ SPM5 } & November & 42.7 & 0.38 & 3.65 & 4.86 & 2.55 & 48.93 \\
\hline & June & 20.9 & 0.22 & 1.61 & 3.18 & 0.90 & 22.74 \\
\hline
\end{tabular}

$M D L$ method detection limit, d.w. dry weight 


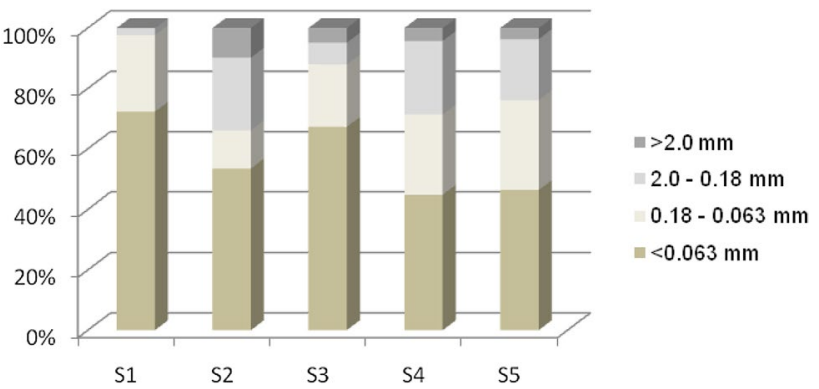

Fig. 2 Distribution of particle size in sediment samples

The concentration of metals in sediments increases with the distance from the source. The highest content of heavy metals was obtained for the S5 sediment which is located at the outlet into the Vistula River. The highest concentrations in the silty-clay fraction were found for zinc $(929 \mathrm{mg} / \mathrm{kg})$, lead $(130.93 \mathrm{mg} / \mathrm{kg})$ and cadmium $(10.40 \mathrm{mg} / \mathrm{kg})$. The highest copper content was determined for S3 (74.92) and nickel $(49.71 \mathrm{mg} / \mathrm{kg})$ for the S2 sample. The results obtained were compared with the local geochemical background values for sediments from the Vistula River according to Helios-Rybicka (1986) and for sediments from Polish rivers estimated by Bojakowska and Sokołowska (1998, Table 6).

The heavy metal concentrations in the sediment samples were compared to the Polish classification on the basis of geochemistry standards (according to Bojakowska and Sokołowska 1998) which indicates different quality classes depending on the metal and the point from which the sediment was collected. In the sampling point $\mathrm{S} 1$, the sediment is classified as class I regardless of the metal. From point $\mathrm{S} 2$ to $\mathrm{S} 4$, the sediment is II class and in the last point (S5) sediment is III class because of the high Cd concentration.

There are some factors that can contribute to the ecological degradation of stream catchments following urbanization. It is often difficult to separate their relative importance because the relationship between urbanization and ecological decline is complex and varies from stream to stream and the relationship between stream condition and catchment land use along the stream are generally complex (Allan 2004; Marshall et al. 2010).

Due to their negative effects on the environment, the concentration of heavy metals in surface waters is regulated in most countries. The situation is much worse in the case of sediments. There are no normative values for determining the quality of water sediments in Polish law. Therefore, various types of classifications and indices are used for this purpose. Additionally, pollution indices and indexes may be an important tool for processing, analysing, and presentation of environmental information to decision-makers, managers, environmentalist and the general public (Sarala and Sabitha 2012).

According to the geoaccumulation index (see Eq. 1, using the values according to Helios-Rybicka (1986) as the geochemical background), at point $\mathrm{S} 1$, the sediment was unpolluted (class 0 ) and in S2 weakly polluted (class 1) because of the $\mathrm{Zn}$ concentration. The concentration of this metal was the reason for sediment at points $\mathrm{S} 3$ and $\mathrm{S} 4$ being classified as moderately polluted (class 2) and in S5 as moderately to heavily polluted (class III, Table 7).

The pollution load index value (Eq. 2) ranges from 1.19 to 1.80 ; the highest was determined for the point located closest to the mouth into the Vistula River (S5). In all sampling points, the moderate pollution with metals was observed (PLI <2, Tomlinson et al. 1980).

Table 6 Characteristic of the bottom sediment

\begin{tabular}{|c|c|c|c|c|c|c|c|c|c|c|c|c|}
\hline Number of sample & $\begin{array}{l}\mathrm{pH} \\
-\end{array}$ & $\begin{array}{l}\mathrm{Eh} \\
(\mathrm{mV})\end{array}$ & $\begin{array}{l}\mathrm{EC} \\
(\mu \mathrm{S} / \mathrm{cm})\end{array}$ & $\begin{array}{l}\mathrm{H}_{2} \mathrm{O} \\
(\%)\end{array}$ & $\begin{array}{l}\text { LOI } \\
(\%)\end{array}$ & $\begin{array}{l}\mathrm{CaCO}_{3} \\
(\mathrm{~g} / \mathrm{kg})\end{array}$ & $\begin{array}{l}\text { Frac- } \\
\text { tion }<0.063 \mathrm{~mm} \\
(\%)\end{array}$ & \multicolumn{3}{|c|}{$\frac{[\mathrm{mg} / \mathrm{kg} \text { fraction }<0.063 \mathrm{~mm}]}{[\mathrm{mg} / \mathrm{kg} \text { raw sediment }]}$} & $\mathrm{Pb}$ & $\mathrm{Zn}$ \\
\hline $\mathrm{S} 1$ & 6.81 & -136 & 870 & 19.15 & 2.96 & 3.65 & 72.31 & $\underline{0.12}$ & $\underline{16.31}$ & $\underline{28.55}$ & $\underline{11.97}$ & $\frac{100.25}{72.49}$ \\
\hline $\mathrm{S} 2$ & 7.08 & -140 & 948 & 15.86 & 6.06 & 13.58 & 53.49 & $\begin{array}{l}0.09 \\
0.16 \\
0.0\end{array}$ & $\begin{array}{l}11.79 \\
\underline{25.72} \\
2.6\end{array}$ & $\begin{array}{l}20.64 \\
49.71 \\
\end{array}$ & $\begin{array}{l}8.66 \\
\underline{20.95} \\
1.1\end{array}$ & $\begin{array}{r}72.49 \\
180.56 \\
0.0\end{array}$ \\
\hline S3 & 7.73 & -199 & 1300 & 22.05 & 25.94 & 57.24 & 67.25 & $\begin{array}{l}0.09 \\
\frac{1.81}{122}\end{array}$ & $\begin{array}{l}13.76 \\
\frac{74.92}{50.38}\end{array}$ & $\begin{array}{l}26.59 \\
\frac{26.22}{17.63}\end{array}$ & $\begin{array}{l}11.21 \\
\frac{5.27}{37.17}\end{array}$ & $\begin{array}{r}96.58 \\
554.11 \\
372.64\end{array}$ \\
\hline $\mathrm{S} 4$ & 7.80 & -217 & 688 & 19.37 & 0.10 & 24.82 & 44.79 & $\frac{1.55}{0.69}$ & $\frac{61.59}{27.59}$ & $\frac{29.59}{13.25}$ & $\frac{46.30}{20.74}$ & $\frac{438.73}{196.51}$ \\
\hline S5 & 7.89 & -197 & 825 & 24.53 & 9.62 & 32.17 & 46.33 & $\frac{10.40}{4.82}$ & $\frac{57.88}{26.82}$ & $\frac{32.49}{15.05}$ & $\frac{130.93}{60.66}$ & $\frac{929.24}{430.52}$ \\
\hline Minimum & 6.81 & -217 & 688 & 19.15 & 0.10 & 3.65 & 44.79 & $\frac{0.12}{0.09}$ & $\frac{16.31}{11.79}$ & $\frac{28.55}{20.64}$ & $\frac{11.97}{8.66}$ & $\frac{100.25}{72.49}$ \\
\hline Maximum & 7.89 & -136 & 1300 & 24.53 & 25.94 & $\mathbf{5 7 . 2 4}$ & 72.31 & $\frac{10.40}{4.82}$ & $\frac{74.92}{50.38}$ & $\frac{49.71}{15.05}$ & $\frac{130.93}{60.66}$ & $\frac{929.24}{430.52}$ \\
\hline $\begin{array}{l}\text { Arithmetic average } \\
\text { Geochemical backgr }\end{array}$ & and for & - & $\begin{array}{l}926 \\
\text { River }(\mathrm{He}\end{array}$ & $\begin{array}{l}\mathbf{2 0 . 1 9} \\
\text { s-Rybic }\end{array}$ & $\begin{array}{r}8.94 \\
1986)\end{array}$ & 26.29 & 56.83 & $\begin{array}{l}\frac{2.81}{1.26} \\
2.0\end{array}$ & $\begin{array}{l}\frac{47.28}{21.18} \\
40.0\end{array}$ & $\begin{array}{l}\frac{33.31}{14.92} \\
40.0\end{array}$ & $\begin{array}{l}\frac{53.08}{23.77} \\
45.0\end{array}$ & $\begin{array}{l}\frac{440.58}{197.34} \\
110.0\end{array}$ \\
\hline Polish geochemical & ckgrol & d (Bojak & wska and & kołowsk & 1998) & & & 0.5 & 6.0 & 5.0 & 10.0 & 48.0 \\
\hline
\end{tabular}

Bold values indicate standard deviation values 
Table 7 Classification of sediment because of selected metal concentrations according to the geo-accumulative index (Müller 1969)

\begin{tabular}{llll}
\hline Metal & Igeo value range & Igeo class & Quality of sediment \\
\hline $\mathrm{Cd}$ & $-4.64 \div 1.79$ & $0(\mathrm{~S} 1-\mathrm{S} 4)$ & Unpolluted \\
& & II (S5) & Moderately polluted \\
$\mathrm{Cu}$ & $-1.88 \div 0.32$ & $0(\mathrm{~S} 1, \mathrm{~S} 2, \mathrm{~S} 5)$ & Unpolluted \\
& & $\mathrm{I}(\mathrm{S} 3, \mathrm{~S} 4)$ & Weakly polluted \\
$\mathrm{Ni}$ & $-1.19 \div-0.27$ & 0 & Unpolluted \\
$\mathrm{Pb}$ & $-2.5 \div 0.96$ & $0(\mathrm{~S} 1-\mathrm{S} 4)$ & Unpolluted \\
& & I (S5) & Weakly polluted \\
$\mathrm{Zn}$ & $-0.72 \div 2.49$ & $0(\mathrm{~S} 1)$ & Unpolluted \\
& & $\mathrm{I}(\mathrm{S} 2)$ & Weakly polluted \\
& & II (S3, S4) & Moderately polluted \\
& & III (S5) & Moderately to heavily \\
& & & polluted \\
\hline
\end{tabular}

Table 8 Classification of sediment quality according to $C_{\mathrm{f}}$ contamination factor and degree of contamination $\left(C_{\mathrm{d}}\right)$

\begin{tabular}{lll}
\hline Metal & $C_{\mathrm{f}}$ value & $\begin{array}{l}\text { Monomial } \\
\text { contamina- } \\
\text { tion factor }\end{array}$ \\
\hline $\mathrm{Cd}$ & 1.41 & Moderate \\
$\mathrm{Cu}$ & 1.18 & Moderate \\
$\mathrm{Ni}$ & 0.83 & Low \\
$\mathrm{Pb}$ & 1.18 & Moderate \\
$\mathrm{Zn}$ & 4.01 & High \\
$\mathrm{Total}\left(C_{\mathrm{d}}\right)$ & 8.61 & $\begin{array}{l}\text { Moderate } \\
\text { degree of } \\
\end{array}$ \\
& & contami- \\
nation
\end{tabular}

The highest value of the contamination factor $\left(\boldsymbol{C}_{\mathrm{f}}\right)$ by Hakanson (1980) (Eq. 4) was obtained for zinc (4.0), while the lowest for nickel (0.8). Similar to PLI index, a moderate degree of contamination $\left(C_{\mathrm{d}}-\mathrm{Eq} .5\right)$ has been found (Table 8).

The extreme variations in the physical and geochemical character of urban streams have negative consequences to environmental quality and aquatic life (Hasenmueller et al. 2017). Metal pollution can modify the structure of algal (Morin et al. 2008) and microbial community (Duarte et al. 2008; Ancion et al. 2010).

The potential ecological risk index (RI) by Hakanson (1980, Eqs. 6 and 7) is calculated as 62.13 for the analysed sediments which indicate low ecological risk for the waterbody. Despite the fact that this value is not high, it should be remembered that it was calculated only on the basis of five metals. Ecotoxicological classification, which is often used to assess the impact of contaminated bottom sediments on aquatic organisms (Smith et al. 1996), was also
Table 9 Comparison of sediment quality ecological indicators by Smith et al. (1996) with average values for the bottom sediments

\begin{tabular}{llllll}
\hline Metal & $\mathrm{Pb}$ & $\mathrm{Cu}$ & $\mathrm{Zn}$ & $\mathrm{Ni}$ & $\mathrm{Cd}$ \\
\hline Average content (mg/kg) & 53.08 & 47.28 & 440.58 & 33.31 & 2.81 \\
PEL (mg/kg) & 91.3 & 197 & 315 & 36.0 & 3.530 \\
TEL (mg/kg) & 35.0 & 35.7 & 123 & 18.0 & 0.596 \\
$\quad$ Samples which exceeded & 20 & 0 & 60 & 20 & 20 \\
$\quad$ PEL (\%) & & & & & \\
$\quad$ Samples which exceeded & 60 & 60 & 80 & 100 & 60 \\
$\quad$ TEL (\%) & & & & & \\
\hline
\end{tabular}

used. All of the analysed metal content exceeded the TEL indicator (Table 9). In the case of $\mathrm{Zn}$, it comprised $80 \%$ of the sediment samples. PEL values for this metal were also exceeded in $60 \%$ of cases. Particularly alarming is the fact that, because of nickel concentration, all sediment samples exceeded the limit value for TEL.

The content of heavy metals in the sediments of the studied stream was compared with data for other tributaries of the Vistula River (Table 10). This confirms the very high concentrations of metals in the analysed watercourse against the background of larger tributaries.

The pollution of aquatic ecosystems with heavy metals is often reflected in their high levels in sediments than in elevated concentrations in water (Linnik and Zubenko 2000; Singh et al. 2005). Such an occurrence is also strongly visible in our studies. This is a dangerous situation because in small watercourses it is common to carry sediments outside the riverbed. In addition, a large amount of metal is transported with the suspended matter.

Some of the Vistula tributaries flow through historical and present mining and smelting areas and transport substantial amounts of contaminants of industrial origin (Aleksander-Kwaterczak and Helios-Rybicka 2009). Water carries pollution mainly from the Biała, Gostynia, Przemsza and Włosienica River basins. The most burdensome is pollution with mineral substances from saline mine water from an Upper Silesian hard coal mine. In Krakow, the largest amount of sewage reaches the Vistula through the tributaries of the Wilga and Drwina Długa, as well as the Dłubnia, Rudawa and Białucha (Pociask-Karteczka 1994). The system of natural watercourses is supplemented by drainage ditches, the total length of which is about $628 \mathrm{~km}$, roadside trenches with a length of $475.8 \mathrm{~km}$ and a rainfall sewage system with a length of about $305 \mathrm{~km}$ with rain inlets. The rainwater drainage system introduces a large load of pollutants into surface waters, as confirmed by Wardas-Lasoń (2014). An additional source of pollution originated from agricultural areas.

It is very important that land cover and land use can exacerbate the effects of metal pollution. The study watercourse is located in the most contaminated district of the Krakow, 
Table 10 Comparison of heavy metal concentrations in investigated sediment samples with values for sediment in other Vistula tributaries in Krakow region

\begin{tabular}{lllllll}
\hline Metal (mg/kg) & $\mathrm{Cd}$ & $\mathrm{Cu}$ & $\mathrm{Ni}$ & $\mathrm{Pb}$ & Zn & Literature \\
\hline Average concentration in the analysed stream & 2.81 & 47.28 & 33.31 & 53.08 & 440.58 & This work \\
Maximum concentration in the analysed stream & 10.40 & 74.92 & 49.71 & 130.93 & 929.24 & Wardas et al. (2006) \\
Prądnik-Białucha & $2.7-7.6$ & $11-77$ & $4-45$ & $44-122$ & $185-732$ & Wr \\
Sudół Dminikański & n.d & $7-73$ & n.d & $16-124$ & $47-943$ & Wardas et al. (2010) \\
Wilga & $1-16$ & $8-184$ & $8-31$ & $15-70$ & $43-372$ & Wardas et al. (2002) \\
Storm spillover sediment_-Vistula's left bank system & $12-13$ & $57-590$ & n.d & $231-320$ & $864-2380$ & Wardas-Lasoń (2014) \\
\hline
\end{tabular}

n.d no data

close to the large steelworks, and has been subjected to heavy metal emission for over 60 years. What's more, the stream flows through built-up areas with a dense network of roads and parking lots. All these factors affect the contamination of the catchment area, and consequently of the studied watercourse. Historical and contemporary contamination can cause very long-term emission of metals to the aquatic environment.

According to the requirements of the European Water Framework Directive (WFD), surface waters should attain "good ecological condition" by the end of 2015, which is denoted by biological, hydromorphological and physiochemical quality elements. As can be seen, this is not an easy matter in the face of a constant inflow of pollutants. Water and sewage management in Krakow still generates pollution, and the environment protection instruments used to date have proven to be insufficient. It seems important to measure the concentration of some elements also in sediments from the small streams, ditches and rain collectors (Wardas-Lasoń 2014). This is why, their research should be introduced to research conducted as part of environmental monitoring. Only management in the catchment system can give some positive results and an answer about the problem of total pollutant load.

\section{Conclusions}

The catchment urbanization is consistently accompanied by decrease of water condition. It is strongly visible not only in the case of rivers but also for small, unmonitored watercourses. The composition of water depends on many natural and anthropogenic factors but changes in chemical composition are generally greater when the water has low flow. Water quality can change very quickly; hence, it is a good medium showing the temporary situation. Contamination of aquatic ecosystems is more often reflected in high pollutant levels in sediments than in water. This is why solid particles may be a much better indicator of the situation occurring in the watercourse.
It is known that land cover and use can have a huge impact on water pollution. The study stream is located in the most contaminated district of the Krakow and has been influenced by heavy metal emission for over 60 years. What's more, the stream flows through built-up areas with a dense network of roads and parking lots. In the case of small watercourse, contaminated sediments are often transported outside the riverbed, and a large number of pollutants can be transported with the suspended matter in the receiver.

The results of heavy metal concentrations in bottom sediment samples indicated contents that exceed the values of the geochemical background and were at a similar level as larger of Vistula River tributaries in Krakow. The interpretation of different sediment indices of quality shows that the greatest problem for the environment may result from cadmium and zinc content. Although the oxidationreducing potential and $\mathrm{pH}$ values, as well as carbonate content, indicate stable chemical forms of the metals, it should be remembered that this form is not stable over time. As a consequence, metals may be remobilized.

According to the requirements of the European Water Framework Directive (WFD), surface waters should attain "good ecological condition" by the end of 2015. As it turned out, it is not easy in a situation of the constant inflow of pollutants. It seems important to measure the concentration of some elements not only in the sediment of the biggest rivers but also in the smaller streams, ditches and rain collectors. Only management in the entire catchment system and inventory of pollution sources can give some positive results in improving the quality of urban watercourses, not only in Krakow but in any other city where similar problems occur.

Acknowledgements The study was supported by AGH-UST 11.11.140.017.

Open Access This article is distributed under the terms of the Creative Commons Attribution 4.0 International License (http://creativeco mmons.org/licenses/by/4.0/), which permits unrestricted use, distribution, and reproduction in any medium, provided you give appropriate 
credit to the original author(s) and the source, provide a link to the Creative Commons license, and indicate if changes were made.

\section{References}

Act on Water Law. Dz.U.2017.1566

Adamiec E (2003) The role of suspended matter in pollution by trace elements in Odra River Wydawnictwa AGH. Krakow

Adamiec E, Helios-Rybicka E (2002) Distribution of pollutants in the Odra River system. Part V. Metals content in the suspended matter and sediments of the Odra River system and recommendations for river chemical monitoring. Pol J Environ Stud 11(6):675-688

Aleksander-Kwaterczak U, Helios-Rybicka E (2009) Contaminated sediments as a potential source of $\mathrm{Zn}, \mathrm{Pb}$, and $\mathrm{Cd}$ for a river system in the historical metalliferous ore mining and smelting industry area of South Poland. J Soils Sediments 9(1):13-22

Aleksander-Kwaterczak U, Sikora WS, Wójcik R (2004) Heavy metals content distribution in grain-size fractions of the Odra River sediments. Geologia 30(20):165-174

Allan JD (2004) Landscapes and rivers capes: the influence of land use on stream ecosystems. Annu Rev Ecol Evol Syst 35:257-284

Ancion PY, Lear G, Lewis GD (2010) Three common metal contaminants of urban runoff $(\mathrm{Zn}, \mathrm{Cu} \& \mathrm{~Pb})$ accumulate in freshwater biofilm and modify embedded bacterial communities. Environ Pollut 158:2738-2745

Backstrom M, Karlsson S, Backman L, Folkeson L, Lind B (2004) Mobilisation of heavy metals by deicing salts in a roadside environment. Water Res 38:720-732

Bannerman RT, Owens DW, Dobbs RB, Hornewer NJ (1993) Sources of pollutants in Wisconsin stormwater. Water Sci Technol 28(3-5):241-259

Barbusiński K, Nocoń W, Nocoń K, Kernert J (2012) The role of suspended solids in the transport of heavy metals in surface water, exemplified by the Kłodnica River. Ochr Śr 34(2):33-38

Bartram J, Balance R (eds) (1996) Water quality monitoring-a practical guide to the design and implementation of freshwater quality studies and monitoring programmes. UNEP/WHO, ISBN 0419 223207

Bernhardt ES, Palmer MA (2007) Restoring streams in an urbanizing world. Freshw Biol 52:738-751

BIP (2015) Public Information Bulletin. www.bip.gov.pl

Bojakowska I, Sokołowska G (1998) Geochemical classes of bottom sediments quality. Przegląd Geologiczny 46(1):49-54

Boyd CE (2015) Water quality: an introduction. Springer, Berlin. https ://doi.org/10.1007/978-3-319-17446-4

Brabec E, Schulte S, Richards PL (2002) Impervious surfaces and water quality: a review of current literature and its implications for watershed planning. J Plan Lit 16:499-514

Cameron EM (1996) Hydrogeochemistry of the Fraser River, British Columbia: seasonal variation in major and minor components. J Hydrol 182:206-225

Das B, Nordin R, Mazumder A (2009) Watershed land use as a determinant of metal concentrations in freshwater systems. Environ Geochem Health 31:595-607

Directive 2000/60/EC of the European Parliament and of the Council of 23 October 2000 establishing a framework for Community action in the field of water policy

Droppo IG (2001) Rethinking what constitutes suspended sediment. Hydrol Process 15:1551-1564

Duarte S, Pascoal C, Alves A, Correia A, Cássio F (2008) Copper and zinc mixtures induce shifts in microbial communities and reduce leaf liter decomposition in streams. Freshw Biol 53:91-101
Dynowski J (1974) Water relations of the city of Krakow. Folia Geogr Ser Geogr Phys 8:103-144

Dz.U. 2011.258.1549. Ministry of environment regulation valid from 9 November 2011, on the classification of the ecological status, ecological potential and chemical status of surface water bodies

Dz.U. 2016.1187. Ordinance of the Minister of the Environment of 21 July 2016 on the on the classification of status of surface waterbodies and environmental quality standards for priority substances

EN ISO 5667-3 (2018) Water quality—sampling-Part 3: preservation and handling of water samples

George R, Martin GD, Nair SM, Thomas SP, Jacob S (2016) Geochemical assessment of trace metal pollution in sediments of the Cochin backwaters. Environ Forensics 17(2):156-171

Ghaleno OR, Sayadi MH, Rezaei MR (2015) Potential ecological risk assessment of heavy metals in sediments of water reservoir case study: Chah Nimeh of Sistan. Proc Int Acad Ecol Environ Sci 5(4):89-96

Grangeon T, Legout C, Esteves M, Gratiot N, Navratil O (2012) Variability of the particle size of suspended sediment during highly concentrated flood events in a small mountainous catchment. J Soils Sediments 12:1549-1558

Hakanson L (1980) An ecological risk index for aquatic pollution-control-a sediment logical approach. Water Resour 14:975-1001

Haris H, Looi LJ, Aris AZ, Mokhtar NF, Ayob NA, Yusoff FM, Salleh A, Praveena SM (2017) Geo-accumulation index and contamination factors of heavy metals $(\mathrm{Zn}$ and $\mathrm{Pb})$ in urban river sediment. Environ Geochem Health 39:1259-1271

Hasenmueller EA, Criss RE, Winston RE, Shaughnessy AR (2017) Stream hydrology and geochemistry along a rural to urban land use gradient. Appl Geochem 83:136-149

Helios-Rybicka E (1986) The role of clay minerals in binding heavy metals by river sediments of the upper Vistula. Geologia 32:7-123

Helios-Rybicka E, Calmano W, Breeger A (1995) Heavy metals sorption/desorption on competing clay minerals; an experimental study. Appl Clay Sci 9(5):369-381

Helios-Rybicka E, Adamiec E, Aleksander-Kwaterczak U (2005) Distribution of trace metals in the Odra River system: water-suspended matter-sediments. Limnologica 35(3):185-198

https://en.wikipedia.org/wiki/File:Vistula_river_map.png\#file. CC BY-SA 3.0. Accessed 12 Dec 2018

https://maps.google.com/. Accessed 12 May 2018

Huang KM, Lin S (2003) Consequences and implication of heavy metal spatial variations in sediments of the Keelung River drainage basin, Taiwan. Chemosphere 53:1113-1121

Ibanez JG, Hernandez-Esparza M, Doria-Serrano C, Fregoso-Infante A, Singh MM (2010) Environmental chemistry: fundamentals. Springer, Berlin

Irmer U (1997) Bedeutung Von Hintergrundwerten für Qualitätsanforderung an Oberflächenwässern. Bewertung der Ergebnisse aus der Elbeschadstof forschung. Geesthacht, pp 36-40

Karnasiewicz JA (2003) Nowa Huta. Crumbs of life and the meanders of history, photo anthology; Wydawnictwo Towarzystwo Slowakow w Polsce, Krakow. ISBN 83-89186-67-5

Kobojek E (2015) Anthropogenic transformation and the possibility of renaturalising small rivers and their valleys in cities——ódź and Lviv examples. Eur Spat Res Policy 22(1):45-60

Kondracki J (2002) Physical geography of Poland. PWN, Warszawa

LAWA-Landesarbeitsgemeinschaft Wasser (1998) Beurteilung der Wasserbeschchaffenheit von Flie $\beta$ gewässern in der Bundesrepublik Deutschland - chemische Gewässergüte- klassifikation. Zielvorgaben zum Schutz oberirdischer Binnengewässer. Band 2, Berlin, 10, 26

Lenart-Boron A, Prajsnar J, Krzesiwo K, Wolanin A, Jelonkiewicz Ł, Jelonkiewicz E, Zelazny M (2016) Diurnal variation in the selected indicators of water contamination in the Białka River 
affected by a sewage treatment plant discharge. Fresenius Environ Bull 25(12):5271-5279

Linnik PM, Zubenko IB (2000) Role of bottom sediments in the secondary pollution of aquatic environments by heavy-metal compounds. Lakes Reserv: Res Manag 5:11-21

Marshall S, Pettigrove V, Carewa M, Hoffmann A (2010) Isolating the impact of sediment toxicity in urban streams. Environ Pollut 158:1716-1725

Meador JP (1991) The interaction of $\mathrm{pH}$, dissolved organic carbon and total copper in the determination of ionic copper and toxicity. Aquat Toxicol 19:13-32

Morin S, Duong TT, Dabrin A, Coynel A, Herlory O, Baudrimont M, Delmas F, Durrieu G, Schafer J, Winterton P, Blanc G, Coste M (2008) Long-term survey of heavy-metal pollution, biofilm contamination and diatom community structure in the Riou Mort watershed, South-West France. Environ Pollut 151:532-542

Müller G (1969) Index of geoaccumulation in sediments of the Rhine River. Geology Journal 2:109-118

Osmulska-Mróz B (1990) Principles of shaping the quality of water in small watercourses in urban areas. In: Basics of water and sewage management in cities and settlements. Instytut Ochrony Środowiska, vol 2, pp 45-72

Paul MJ, Meyer JL (2001) Streams in the urban landscape. Annu Rev Ecol Syst 32:333-365

PN-B-02480 (1998) Building land—definitions. Symbols. Division and description of land. Polish Committee for Standardization

PN-EN ISO 10304-1 (2009) Water quality-determination of dissolved anions by liquid chromatography of ions-Part 1: determination of bromide, chloride, fluoride, nitrate, nitrite, phosphate and sulfate

PN-EN ISO 10693 (2014-06) Soil quality-determination of carbonate content-volumetric method

PN-EN ISO 11885 (2009) Water quality-determination of selected elements by inductively coupled plasma optical emission spectrometry (ICP-OES)

PN-EN ISO 14911 (2002) Water quality-determination of dissolved $\mathrm{Li}^{+}, \mathrm{Na}^{+}, \mathrm{NH}^{4+}, \mathrm{K}^{+}, \mathrm{Mn}^{2+}, \mathrm{Ca}^{2+}, \mathrm{Mg}^{2+}, \mathrm{Sr}^{2+}$ and $\mathrm{Ba}^{2+}$ using ion chromatography-Method for water and waste water

PN-EN ISO 17294-1 (2007) Water quality: application of mass spectrometry with inductively coupled plasma (ICP-MS)

Pociask-Karteczka J (1994) Changes of water relations in the area of Krakow. Scientific papers of the Jagiellonian University MCXLIV Prace Geograficzne, vol 96, pp 7-53

Rajda W, Kanownik W (2005) Monitoring and water quality assessment within the small stream situated at the residential and suburban area. Acta Hortic Regiotect 8:278-281

Sajdak M, Siwek J, Bojarczuk A, Żelazny M (2018) Hydrological and chemical water regime in the catchments of Bystra and Sucha Woda, in the Tatra National Park. Acta Sci Pol Formatio Circumiectus 17(3):161-173

Sarala TD, Sabitha MA (2012) Calculating integrated pollution indices for heavy metals in ecological geochemistry assessment near Sugar Mill. J Res Biol 2(5):489-498

Shafie NA, Aris AZ, Haris H (2014) Geoaccumulation and distribution of heavy metals in the urban river sediment. Int J Sediment Res 29(3):368-377
Shomar BH, Müller G, Yahya (2005) A seasonal variations of chemical composition of water and bottom sediments in the wetland of Wadi Gaza, Gaza Strip. Wetl Ecol Manag 13(4):419-431

Singh KP, Mohan D, Singh VK, Malik A (2005) Studies on distribution and fractionation of heavy metals in Gomti River sediments-a tributary of the Ganges, India. J Hydrol 312(1-4):14-27

Smith SL, MacDonald DD, Keenleyside KA, Ingersoll CG, Field LJ (1996) A preliminary evaluation of sediment quality assessment values for freshwater ecosystems. J Great Lakes Res 22:624-638

Tomczyk NJ, Parr TB, Wenger SJ, Capps KA (2018) The influence of land cover on the sensitivity of streams to metal pollution. Water Res 144:55-63

Tomlinson DC, Wilson JG, Harris CR, Jeffery DW (1980) Problems in the assessment of heavy metals levels in estuaries and the formation of a pollution index. Helgol Mar Res 33:566-575

Tyczyńska M (1968) The sculpture and geological structure of the city of Krakow. In: Geographical environment of the city of Krakow. PAN Krakow

UE Water Framework Directive 2000/60/EC; Directive of the European Parliament and of the Council of 23 October 2000 establishing a framework for Community action in the field of water policy

Walsh CJ, Roy AH, Feminella JW, Cottingham PD, Groffman PM, Morgan RP (2005) The urban stream syndrome: current knowledge and the search for a cure. J N Am Benthol Soc 24:706-723

Wardas M, Pawlikowski M, Korzeniak A, Basińska A, Szota R, Kłek M (2002) Heavy metals in sediments of water and wastewater system in Krakow. Environ Prot Eng 28(1):35-41

Wardas M, Aleksander-Kwaterczak U, Łojan E, Woźniak P, Wolski Ł (2006) Defining of the sources and the estimation of the pollution of heavy metals in the bottom sediments in the Prądnik-Białucha River in Krakow in order to determine ecological potential. Infrastruktura i ekologia Terenów Wiejskich 4(3):161-169

Wardas M, Aleksander-Kwaterczak U, Jusik S, Hryc B, Zgoła T, Sztuka M, Kaczmarska M, Mazurek M (2010) An attempt to assess the impact of anthropopressure on the ecological state of urbanized watercourses of Krakow conurbation and the difficulties encountered. J Elementol 15(4):725-743

Wardas-Lason M (2014) The influence of sewage system on the functioning and quality of Krakow's watercourses. J Geol Res 1-13. ID 910982. http://dx.doi.org/10.1155/2014/910982

Wilson J, Michail L, Shaldybin MV (2016) Clay mineralogy and unconventional hydrocarbon shale reservoirs in the USA. II. Implications of predominantly illitic clays on the physico-chemical properties of shales. Earth Sci Rev 158:1-8

Yao Q, Wang X, Jian H, Chen H, Yu Z (2015) Characterization of the particle size fraction associated with heavy metals in suspended sediments of the Yellow River. Int J Environ Res Public Health 12:6725-6744

Zhao Y, Marriott S, Rogers J, Iwugo K (1999) A preliminary study of heavy metal distribution on the floodplain of the River Severn, UK by a single flood vent. Sci Total Environ 243(244):219-231

Publisher's Note Springer Nature remains neutral with regard to jurisdictional claims in published maps and institutional affiliations. 